\title{
PENGEMBANGAN MODUL PEMBELAJARAN BIOLOGI BERBASIS ANDROID PADA MATERI SISTEM REGULASI UNTUK SISWA SMA/MA
}

\author{
Halmi Pratama ${ }^{1 *}$, Eliwatis $^{2}$, Najmiatul Fajar ${ }^{1}$ \\ ${ }^{1}$ Jurusan Tadris Biologi, Fakultas Tarbiyah dan Ilmu Keguruan, IAIN Batusangkar \\ ${ }^{2}$ Jurusan Pendidikan Agama Islam, Fakultas Tarbiyah dan Ilmu Keguruan, IAIN Batusangkar \\ Jalan Sudirman No. 137 Lima Kaum Batusangkar, Kab. Tanah Datar \\ *Email: halmipratama7@gmail.com
}

\begin{abstract}
Technology that is developing at this paper are believed can help teachers to create learning media. For example, is the use of technology in m-learning's virtual learning media which can be applied to android smartphones. Learning that is currently happening is only conventional and the use of instructional media by teachers has not developed according to technological progress and the use of these technologies has not been applied in learning. Therefore, research is carried out which aims to produce an android-based biology learning module about the material of the regulatory system for SMA / MA students who are valid and practice. This research development using three of the four stages of the development model of 4-D Models, which consist of defining phases, design phases, develop phases, distribution phases (disseminate). The data of this study are primary data obtained from the validation sheet and practicality test questionnaire, then analyzed by descriptive analysis. This research produces a product in the form of a valid and practical biology-based learning module. Based on the validator's assessment, the android-based biology learning module is categorized as very valid (82.84). Based on the assessment of androidbased biology subject teachers in the very practical category, the average results of 87.92 were obtained and based on the assessment of students the biology learning module was categorized as very practical and obtained an average value of 86.6. The Android-based biology learning module that the researchers developed is feasible to use in the learning process.
\end{abstract}

Keywords: Learning Module, Android Smartphone Technology, m-learning.

\section{PENDAHULUAN}

Teknologi saat ini berkembang demikian pesat, terutama teknologi telekomunikasi yang telah membawa perubahan besar dalam pendidikan dan pembelajaran. Guru seharusnya mampu memanfaatkan teknologi yang ada untuk mengembangkan media pembelajaran, dimana orang yang disebut guru adalah orang yang memiliki kemampuan merancang program pembelajaran, serta mampu menata dan mengelola kelas agar siswa dapat belajar dan pada akhirnya dapat mencapai tingkat kedewasaan sebagai tujuan akhir dari proses pendidikan (Suprihatiningrum, 2014).

Perkembangan ilmu pengetahuan dan teknologi semakin mendorong upaya dalam proses belajar, guru dituntut agar mampu menggunakan alat-alat yang disediakan disekolah dan tidak tertutup kemungkinan bahwa alat-alat tersebut sesuai dengan perkembangan dan tuntutan zaman (Arsyad, 2010). Dengan hal ini bahwa salah satu keterampilan yang harus dimiliki guru adalah merancang, menciptakan, atau memodifikasi media sederhana, membuat media elektronik atau multimedia. 
Pendidikan merupakan suatu rekayasa untuk mengendalikan learning guna mencapai tujuan yang direncanakan serta efektif dan efisien. Teknologi dan informasi dapat dimanfaatkan dalam membuat media pembelajaran mandiri salah satunya melalui media elektronik mobile atau yang lebih tepatnya disebut dengan mobile learning $(m-$ learning). M-learning sebenarnya merupakan salah satu jenis e-learning. Hal ini sesuai dengan pendapat (Sutopo, 2012) bahwa sistem teknologi yang tersedia dan dapat digunakan dalam e-learning salah satunya berupa $m$ learning berhubungan dengan pembelajaran menggunakan perangkat mobile seperti PDAs, mobile phone, laptop, dan peralatan teknologi informasi lain untuk pembelajaran M-learning merupakan bentuk pembelajaran yang khusus memanfaatkan perangkat dan teknologi komunikasi. Diantara beragam perangkat tersebut, handphone memiliki persentase yang tinggi dimiliki oleh setiap orang dan lebih sederhana dalam menggunakannya dari pada perangkat lain Jumlah pengguna handphone di Indonesia tercatat sebanyak 116 juta dan menempati urutan ke-6 terbanyak di dunia.

Salah satu jenis handphone adalah smartphone dengan sistem operasi Android. Smartphone Android kini tidak hanya dimiliki oleh orang dewasa, tetapi juga dimiliki oleh pelajar pada tingkat sekolah menengah bahkan sekolah dasar. Berdasarkan hasil observasi peneliti tanggal 8 Oktober 2016 di kelas XI IPA SMAN 1 Salimpaung, diketahui banyak siswa yang memiliki smartphone Android. Namun umumnya siswa baru menggunakan smartphone Android sebatas untuk SMS (Short Massage Service), telepon, chatting, internet, dan hiburan seperti bermain game, mendengarkan musik dan berfoto. Dari hasil observasi diketahui belum banyak siswa memanfaatkan smartphone Android sebagai media atau alat untuk belajar.

Berdasarkan hasil wawancara dengan siswa kelas XI IPA SMAN 1 Salimpaung, diketahui bahwa siswa kurang tertarik dan cenderung bosan dengan sumber belajar berupa media cetak seperti buku yang bersifat konversional saja dan buku yang digunakan di sekolah terlalu banyak sumber yang digunakan dalam pembelajaran. Begitupun dengan hasil wawancara dengan guru mata pelajaran biologi guru hanya menggunakan media pembelajaran yaitu media cetek berupa modul pembelajaran dan buku-buku yang ada di perpustakaan.

Keterbatasan guru dalam mengembangkan media pembelajaran membuat siswa kurang tertarik belajar biologi karna media yang digunakan oleh guru tersebut hanya bersifat media cetak. Hal ini tergambar dari sedikitnya jumlah siswa yang memiliki buku sumber. Ketidaktertarikan siswa terhadap buku cetak antara lain disebabkan pada buku tersebut gambar pendukungnya kurang menarik sehingga siswa malas membaca serta tampilan dari buku dan modul yang digunakan oleh guru tersebut belum bisa menarik minat membaca dari siswa tersebut. Hal ini diperburuk lagi dengan minimnya penggunaan media oleh guru dalam pembelajaran sehingga mengakibatkan kurangnya motivasi siswa dalam mengikuti pembelajaran. Alasan lain dari sedikitnya siswa membawa buku adalah karena mereka merasa terbebani karena buku yang digunakan di dalam pembelajaran terlalu banyak sumber pembelajaran yang digunakan sehingga siswa menjadi kurang tertarik dalam pembelajaran. Ada beberapa orang siswa meninggalkan sebagian bukunya di sekolah. Keadaan ini menjadikan proses belajar di rumah dan di sekolah kurang efektif. Adapun alasan lainnya siswa mengakui kalau dirumah, lebih banyak menghabiskan waktu dengan smartphone Android yang dimilikinya dari pada membaca buku.

Berdasarkan permasalahan tersebut, peneliti mengusulkan suatu alternatif solusi berupa modul pembelajaran, dengan menggunakan modul yang disajikan oleh peneliti yang menuntut siswa lebih termotivasi dalam pembelajaran dan menarik minat baca siswa dalam pembelajaran. Oleh sebab itu, akan efektif ketika dilakukan pengalihan fungsi buku pembelajaran ke smartphone dengan cara memasukkan modul pembelajaran biologi ke dalam smartphone Android yang dimiliki siswa. Berdasarkan permasalahan tersebut, peneliti mengusulkan suatu alternatif solusi 
berupa modul pembelajaran berbasis android yang berjudul "Pengembangan Modul Pembelajaran Biologi Berbasis Android pada Materi Sistem Regulasi Untuk Siswa SMA/MA".

Rumusan masalah dalam penelitian ini adalah: Bagaimana validitas modul pembelajaran berbasis android tentang materi sistem regulasi untuk siswa SMA/MA. Dan bagaimana partikalitas modul pembelajaran berbasis android tentang materi sistem regulasi untuk siswa. Tujuan penelitian ini adalah untuk menghasilkan modul pembelajaran biologi berbasis android tentang materi sistem regulasi untuk siswa SMA/MA yang valid dan praktis.

Penelitian ini menghasilkan produk yang berupa sebuah modul pembelajaran yang memiliki karakteristik sebagai berikut:

a. Modul pembelajaran yang dikembangkan dalam penelitian ini adalah bahan yang dimasukkan ke dalam perangkat android dengan kapasitas memori kurang dari 45 MB

b. Modul pembelajaran ini tidak membutukan koneksi internet untuk mengaksesnya, sehingga dapat digunakan dimanapun dan kapanpun sesuai dengan kebutuhan siswa.

c. Modul pembelajaran berbasis android yang dikembangkan memiliki halaman utama yang berisi beberapa Ikon, yaitu: Identitas Modul, Peta Konsep, Materi, Rangkuman, Evaluasi

d. Modul pembelajaran disusun dengan bahasa indonesia yang sederhana dan jelas sehingga mudah dipahami oleh siswa

e. Pembuatan modul pembelajaran ini menggunkan aplikasi Android Studio dan Java Developmen Kit (JDK)

\section{METODE PENELITIAN}

Jenis penelitian ini digolongkan ke dalam penelitian pengembangan (Research and Development). Penelitian pengembangan adalah metode penelitian yang digunakan untuk menghasilkan produk tertentu dan menguji keefektifan dan kevalidan produk tersebut (Sugiyono, 2007).
Model pengembangan yang dirancang dalam penelitian ini memakai model pengembangan 4-D terdiri atas 4 tahap pengembangan, yang disarankan oleh Tiagarajan, dan Sammel yaitu define (pendefinisian), design (perancangan), develop (Pengembangan), dan disseminate (Penyebaran). (Trianto, 2012) karena keterbatasan waktu dan biaya peneliti hanya sampai pada tahap develop (pengembangan). Tahapan dari pengembang modul tersebut diantaranya.

\section{Tahap define (pendefinisian)}

Pada tahap define dilakukan penetapan dan pendefinisian kebutuhan pembelajaran menggunakan modul pembelajaran biologi berbasis Android. Tahapan ini memiliki 5 langkah yang dilakukan pada tahap ini yaitu:

1. Analisis Ujung Depan

Analisis ujung depan bertujuan untuk mengidentifikasi masalah dasar yang dihadapi guru dan siswa dalam pembelajaran biologi. Analisis ini dilakukan dengan mewawancarai guru biologi dan siswa kelas XI IPA SMAN 1 Salimpaung terkait dengan permasalahan yang terjadi dalam pembelajaran dan media yang digunakan dalam pembelajaran, serta fasilitas yang disediakan di sekolah. Kemudian mencari alternatif untuk pemecahan masalah dalam pembelajaran biologi tersebut.

2. Analisis Siswa

Analisis siswa bertujuan untuk mengidentifikasi target pembelajaran yaitu siswa. Analisis ini dilakukan melalui observasi lansung ke dalam proses pembelajaran dan mengamati jalanya proses pembelajaran secara lansung dengan meliputi pengamatan karakteristik pada siswa saat mereka belajar.

3. Analisis Tugas

Analisis tugas dilakukan untuk mengidentifikasi dan menganalisis kemampuan yang harus dikuasai siswa melalui penentuan isi dalam satuan pembelajaran yang sesuai dengan Kurikulum 2013. Analisis ini dilakukan dengan cara menganalisis Kompetensi Inti (KI) dan Kompetensi Dasar (KD) dari materi sistem regulasi, kemudian dilakukan perumusan indikator.

4. Analisis Konsep 
Analisis konsep dilakukan dengan cara mengidentifikasi konsep-konsep utama pada materi sistem regulasi. Konsep-konsep utama yang akan diajarkan disusun secara sistematik serta sesuai urutan materi dan konsep-konsep materi pelajaran agar mudah dipahami oleh siswa.

5. Perumusan Tujuan Pembelajaran

Analisis tujuan pembelajaran dijadikan dasar untuk merancang perencanaan pengembangan modul pembelajaran biologi. Acuan dari tujuan pembelajaran ini adalah indikator pembelajaran yang telah dibuat.

\section{Tahap design (Perancangan)}

Tahap perancangan dilakukan dengan menyiapkan materi pembelajaran yang akan ditampilkan pada modul pembelajaran biolgi. Hal ini dimulai setelah tujuan-tujuan pembelajaran dibuat. Ada tiga langkah pada tahap ini yaitu:

6. Pemilihan Perangkat Pembelajaran

Pemilihan perangkat pem-belajaran sesuai dengan analisis tugas, analisis konsep, karakteristik siswa serta tujuan untuk menyampaikan materi pembelajaran.

7. Pemilihan Format

Pemilihan format disesuaikan dengan format yang diperlukan dalam modul pembelajaran biologi tersebut.

8. Perancangan Awal:

Adapun rancangan awal dari pembuatan modul pembelajaran biologi berbasis android ini sebagai berikut:

a) Menganalisis materi sistem regulasi sebagai bahan dalam modul pembelajaran biologi berbasis android. Menyusun konsep materi sistem regulasi yang telah dianalisis.

b) Mencari dan mempersiapkan gambar-gambar beserta video yang akan ditampilkan pada modul pembelajaran biologi berbasis android.

c) Membuat modul pembelajaran biologi dalam format Microsoft Office Word.

d) Merancang tampilan opening pada modul pembelajaran biologi.

e) Merancang halaman menu utama modul pembelajaran biologi berbasis android, diantaranya: Identitas Modul, Peta Konsep, Materi, Rangkuman, dan Evaluasi. f) Merancang tampilan halaman menu materi pelajran dan evaluasi pembelajaran.

g) Membuat modul pembelajaran biologi ke dalam bentuk aplikasi Android menggunakan aplikasi Android Studio dan Java Kit Development.

\section{Tahap develop (Pengembangan)}

Tahap ini bertujuan untuk menghasilkan modul pembelajaran biologi berbasis android yang telah divalidasi dan direvisi berdasarkan masukan dari para ahli pendidikan (validator). Dan kemudian dilakukan uji praktikalitas dilakukan oleh guru mata pelajaran biologi dan siswa kelas XI IPA SMAN 1 Salimpaung untuk melihat kepraktisan produk yang telah dikembangkan. Kriteria praktikalitas diketahui dari angket uji praktikalitas yang telah disediakan oleh peneliti dan diisi oleh guru dan siswa

\section{HASIL PENELITIAN}

Pengembangan dan penelitian modul pembelajaran biologi berbasis android ini dilaksanakan dengan tiga tahapan, yaitu: pendefinisian (define), perancangan (design), dan pengembangan (develop). Hasil dari proses pada masing-masing tahapan adalah sebagai berikut

\section{Tahap pendefenisian (define)}

Tahap ini diawali dengan wawancara dengan guru mata pelajaran Biologi di SMAN 1 Salimpaung, di dalam tahapan ini ada beberapa hal yang analisis diantaranya

1) Analisis Ujung Depan

Analisis ujung depan dilakukan dengan mewawancarai guru mata pelajaran biologi dan siswa kelas XI IPA SMAN 1 Salimpaung. Hasil wawancara dengan guru biologi terungkap bahwa penggunaan media dalam pembelajaran masih belum optimal sehingga siswa kurang termotivasi dalam mengikuti pembelajaran. Hasil wawancara dengan 21 orang siswa kelas XI IPA diketahui bahwa pada umumnya sumber belajar siswa berupa buku paket dan modul pembelajaran yang di rancang oleh guru tersebut. Menurut siswa gambar yang terdapat pada modul pembelajaran 
yang dibuat oleh guru tersebut kurang jelas dan kurang menarik sehingga siswa malas membaca.

2) Analisis Siswa

Analisis siswa didapatkan melalui observasi langsung dalam kegiatan proses pembelajaran. Berdasarkan hasil observasi diketahui bahwa siswa kelas XI IPA memiliki rentang usia 16-17 tahun.

3) Analisis Tugas

Analisis tugas dilakukan dengan cara menganalisis Kompetensi Inti (KI) dan Kompetensi Dasar (KD) dari materi sistem regulasi yang terdapat di dalam silabus, adapun Kompetensi Inti (KI), Kompetensi Dasar (KD).

4) Analisis Konsep

Analisis konsep dilakukan dengan cara mengidentifikasi konsep-konsep utama yang terdapat di dalam materi sistem regulasi yang harus dipahami oleh siswa. Konsep-konsep yang harus dipahami oleh siswa diantaranya adalah struktur sistem regulasi, pembagian sistem regulasi fungsi yang terdapat dalam pembagian sistem regulasi, serta kelainan atau penyakit yang terdapat dalam sistem regulasi

5) Perumusan Tujuan Pembelajaran

Tujuan dari pembelajaran materi sistem regulasi yang di rancang berdasarkan indikator yang digunakan guru bersangkutan.

\section{Tahap Perancangan (design)}

Tahap perancangan dilakukan dengan menyiapkan materi pembelajaran yang akan ditampilkan pada modul pembelajaran biologi berbasis android dimana semua Kompensi Dasar, Indikator, Materi, Video, Rangkuman, dan Evaluasi dibuat di dalam Microsoft Office Word 2007, dan mendownload aplikasi Android Studio dan Java Kit Development. karena dibuat di dalam Aplikasi Software harus dirancang terlebih dahulu di dalam Microsoft Office Word supaya mendapatkan hasil yang lebih baik. Adapun rancangan awal dari pembuatan modul pembelajaran biologi berbasis android ini sebagai berikut:

1) Merancang bentuk tampilan modul pembelajaran biologi berbasis android

a) Tampilan Pembuka (Opening)

Pada tampilan pembuka terdapat identitas peneliti sekaligus menjadi cover dalam pembuatan modul pembelajaran biologi ini, tampilan ini diberi waktu sekitar beberapa detik untuk masuk kedalam tampilan berikutnya. Untuk tampilan pembuka awalnya seperti terdapat pada Gambar 1.a kemudian diberi masukan oleh validator sekaligus merevisi tampilan dari modul pembelajaran berbasis android kemudian di revisi menjadi tampilan opening yang baru seperti terdapat pada Gambar 1.b.

\section{b) Identitas Modul}

Tampilan pada identitas modul ini terdapat kompetensi dasar, indikator yang terdapat di dalam silabus dan tujuan pembelajaran yang jelas dari indikator (lihat Gambar 2).

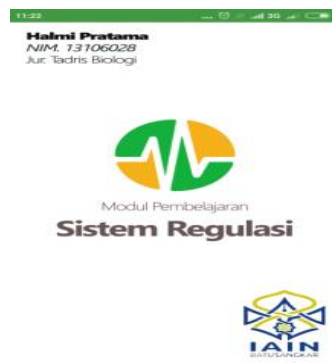

(a)

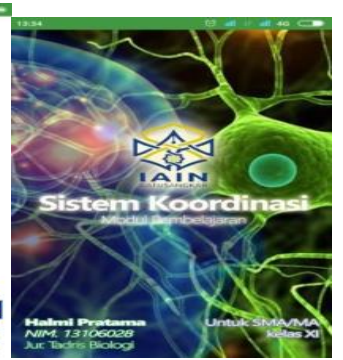

(b)

Gambar 1. Tampilan Pembuka (a) Sebelum Revisi dan (b) Sesudah Revisi 
Dengan adanya identitas modul ini pembelajaran dapat menjadi lebih terarah. Untuk menuju ikon berikutnya cukup menggeser layar smartphone androidnya ke kiri atau ke kanan.

c) Peta konsep

Tampilan peta konsep dirancang untuk memudahkan siswa dalam memahami materi yang nanti akan di pelajarinya, tampilan peta konsep ini diberi masukan dalam penyempurnaan berfungsi untuk agar orang yang bukan biologi juga dapat memahami isi dari modul pembelajaran biologi ini (lihat Gambar 3). Pemilihan warna tersebut merupakan warna yang lembut.

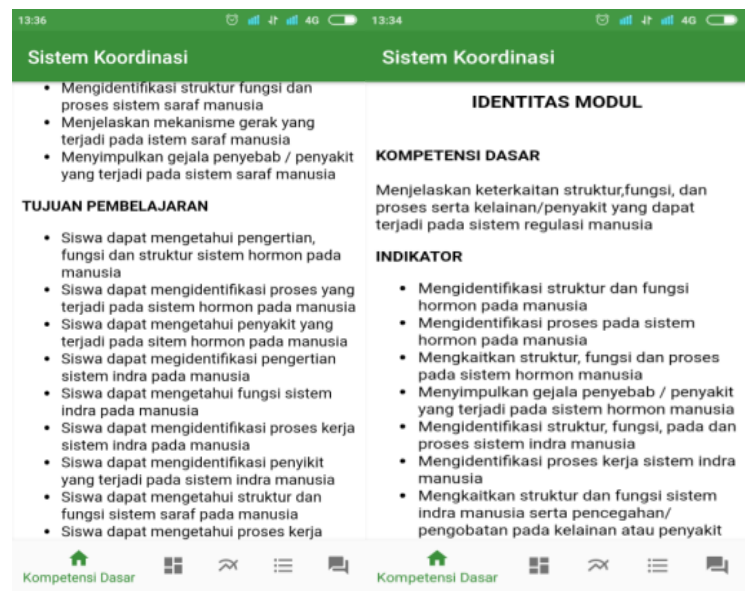

Gambar 2. Identitas Modul

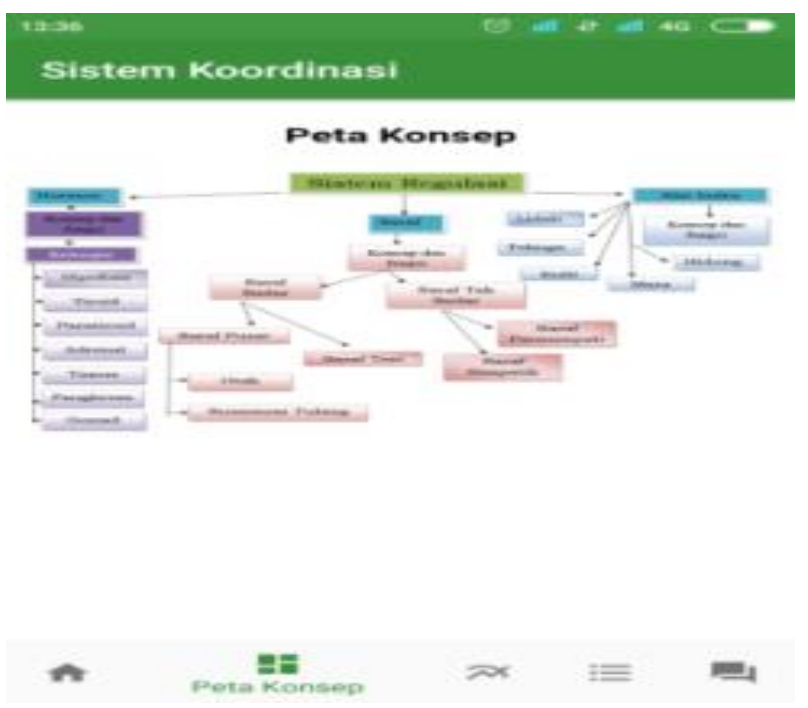

Gambar 3. Peta Konsep 
d) Tampilan Materi
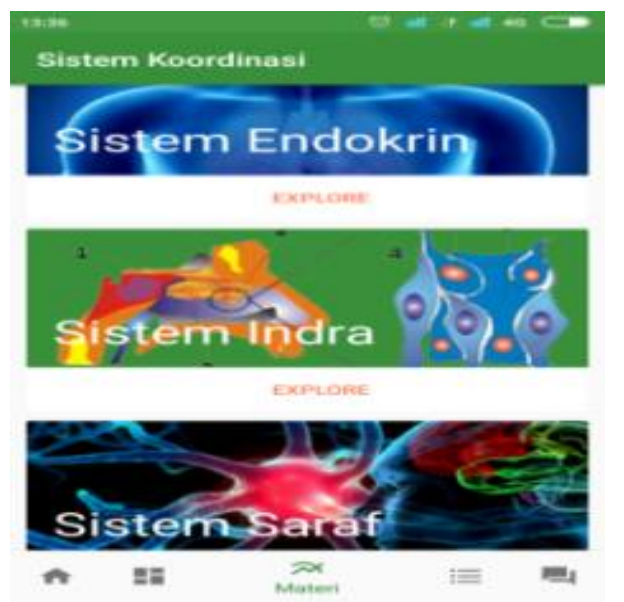

Gambar 4. Tampilan Opening Materi

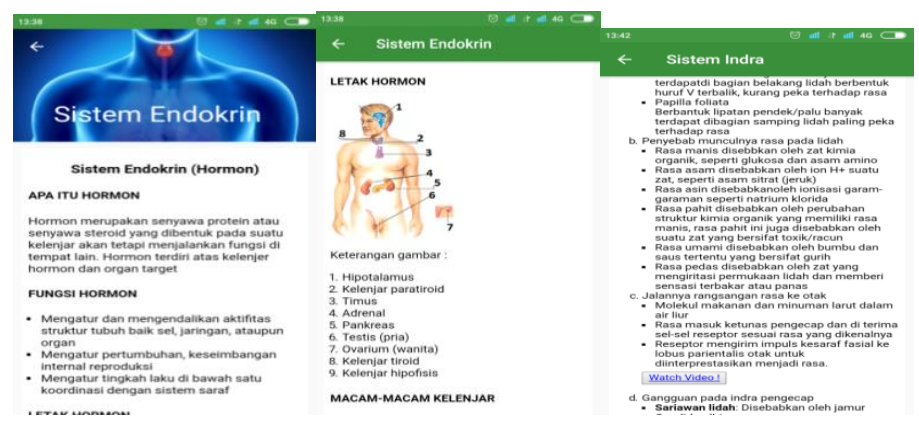

Gambar 5. Sistem Endokrin

Di dalam ikon tampilan materi sistem koordinasi dibagi atas 3 sub materi diantaranya sistem koordinasi, sistem indera, sistem saraf (lihat Gambar 4). Ketiga ikon sub menu ini memuat pembahasan dari masing-masing sub menu dan terdapat gambar-gambar yang menunjang pembahasan dalam materi tersebut dan juga terdapat video-video pendukung dalam pemahaman dari materi pembelajaran dan kelainan yang terdapat dalam sistem regulasi dari modul tersebut. contoh dari tampilan materi tersebut dapat dilihat pada Gambar 5.
Di dalam materi sistem endokrin membahas struktur, fungsi, macam-macam kelenjer dan gangguan pada sistem endokrin materi ini dibuat dari beberapa buku sumber dan ditambahkan gambar yang dapat menunjang pemahaman siswa. Kemudian pada sub materi sistem indera juga membahas mengenai alat indera, struktur, mekanisme kerja alat indera dibantu dengan tambahan video untuk menambah pemahaman siswa, dan gangguan yang terjadi pada alat indera (lihat Gambar 6). 
Sedangkan mengenai sub materi sistem koordinasi dibahas mengenai struktur, macammacam, susunan serta gerak pada saraf, dan kelainan yang terjadi pada sistem koordinasi, dan juga dibantu dengan video dalam pemahaman materi mengenai sistem koordinasi ini (lihat Gambar 7). e) Tampilan Rangkuman

Tampilan menu rangkuman ini menyangkut kepada seluruh materi yang ada dalam sistem regulasi untuk menambah pemahaman siswa pada menu Rangkuman yaitu mencakup semua materi yang terdapat di dalam sub materi sistem regulasi (lihat Gambar 8).

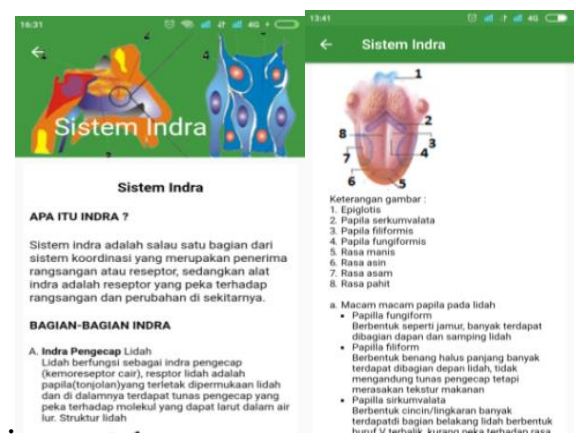

Gambar 6. Sistem Indera

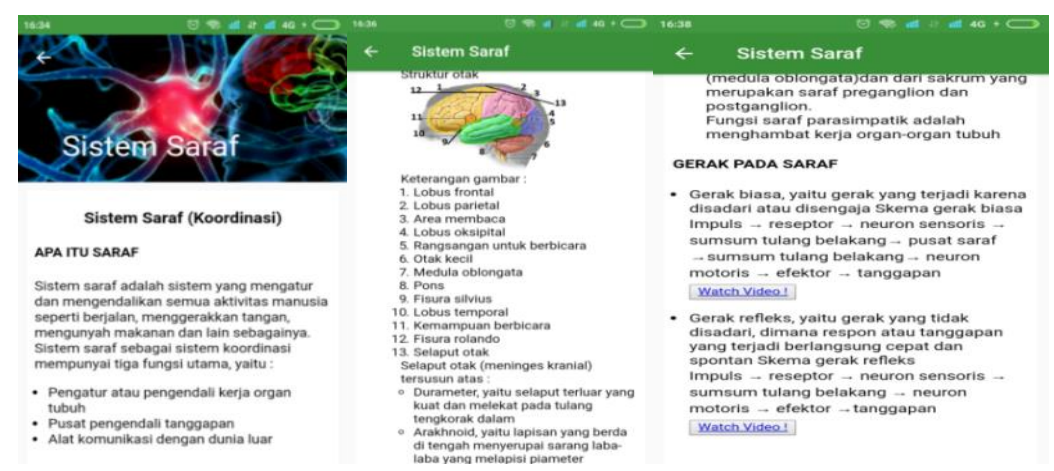

Gambar 7. Sistem Koordinasi

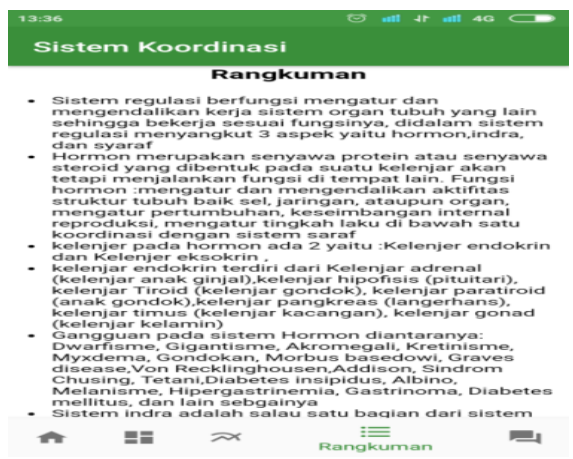

Gambar 8. Rangkuman 


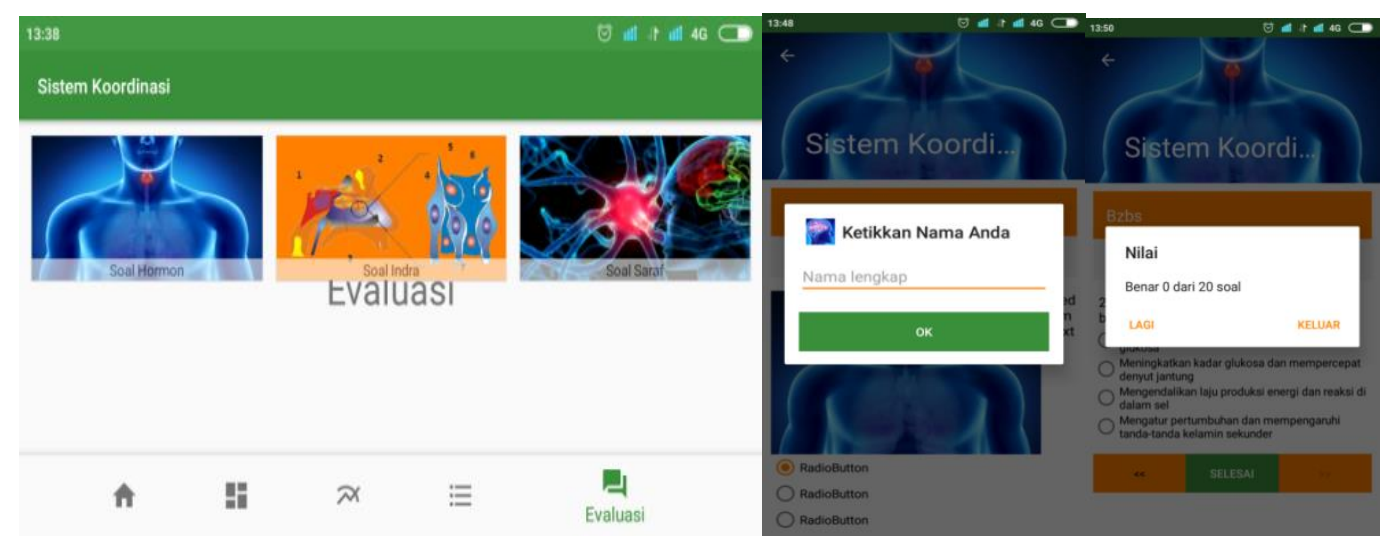

Gambar 9. Tampilan Evaluasi

f) Tampilan Evaluasi

Tampilan evaluasi berisi soal-soal untuk mengukur pemahaman siswa tentang materi sistem regulasi. Soal-soal pada masing-masing sub evaluasi berjumlah 20 butir, hasil jawaban dari sub evaluasi akan keluar apabila telah selesai mengerjakan soal-soal yang terdapat pada sub evaluasi. Sebelum menjawab soalsoal evaluasi siswa harus mengisikan nama agar dapat menjawab soal tersebut.Tampilan halaman-halaman pada sub evaluasi dapat dilihat pada Gambar 9.

\section{2) Pengumpulan Bahan}

Bahan yang digunakan untuk mengembangkan modul pembelajaran biologi berbasis android ini menggunakan buku-buku yang disediakan dari perpustakaan IAIN Batusangkar dan E-Book. Buku-buku tersebut dijadikan rujukan untuk membuat materi di dalam modul pembelajaran biologi berbasis android dan gambar yang digunakan dalam materi serta video yang digunakan di download di internet dan you tube.

3) Merancang Instrumen Penelitian

Instrumen yang dirancang akan dijadikan variable untuk mengetahui validitas dan praktikalitas media yang dibuat.

a. Tahap Pengembangan (develop)
Tahap pengembangan bertujun untuk mengetahui tingkat kevalidan serta kepraktisan dari media yang telah diuji cobakan. Berikut ini uraian hasil validitas dan praktikalitas dari modul pembelajaran biologi berbasis android.

\section{a. Validasi modul pembelajaran biologi berbasis android}

Modul pembelajaran biologi berbasis android yang dirancang selanjutnya divalidasi oleh 3 orang pakar pendidikan dan pakar biologi diataranya 2 orang dosen dan 1 orang guru mata pelajaran adapun hasil validasinya terdapat dalam tabel, yang divalidasi ada memenuhi 4 syarat diataranya: Syarat didaktik, Syarat konstruksi, Syarat teknis, dan Syarat kebahasaan. Hasil ini menunjukan rata-rata nilai sebesar 82,84 dengan kategori sangat valid. Hal ini menunjukkan bahwa modul pembelajaran biologi berbasis android yang dikembangkan telah valid dari ke 4 aspek tersebut. Dalam pengembangannya masing-masing penilaian yang diberikan oleh validator, tiap-tiap validator memberikan nilai yang sangat baik dan memuaskan.

Dilihat dari skor yang diberikan oleh masing-masing validator terhadap modul pembelajaran biologi berbasis android yang dikembangkan dinyatakan valid dan layak dilakukan uji cobakan kepada siswa kelas XI 
IPA SMAN 1 Salimpaung yang jumlah siswanya sebanyak 21 orang.

\section{b. Praktikalisasi modul pemblajaran biologi berbasis android}

Modul yang telah divalidasi selanjutnya dilkukan uji praktikalitas. Uji praktikalitas modul pembelajaran biologi berbasis android dilakukan kepada guru dan siswa. Data praktikalitas yang dilakukan oleh guru yaitu ibu Hefni Khaira, S.Pd diperoleh menggunakan angket uji praktikalitas. Penelitian menunjukkan bahwa nilai praktikalitas modul pembelajaran biologi berbasis android adalah 87,92 dengan kriteria sangat praktis, hal ini menunjukkan bahwa modul pembelajaran biologi berbasis android praktis untuk digunakan oleh guru sebagai salah satu media pembelajaran.

Selain guru uji praktikalitas dilakukan terhadap siswa bertujuan untuk mengumpulkan informasi mengenai penilaian siswa terhadap modul pembelajaran biologi berbasis android. Hasil yang diperoleh menjelaskan bahwa nilai praktikalitas modul pembelajaran biologi berbasis android yang dilakukan pada siswa SMAN 1 Salimpaung sebanyak 21 orang di dapat hasil 86.6 dangan kriteria sangat valid. Hal ini menunjukan bahwa modul pembelajaran biologi berbasis android yang dikembangkan sangat praktis digunakan siswa dalam pembelajaran biologi di sekolah maupun di luar perkarangan sekolah.

\section{Pembahasan}

Produk yang dikembangkan berupa modul pembelajaran biologi berbentuk aplikasi android yang diakses pada smartphone dengan tujuan untuk mengembangkan sebuah modul pembelajaran biologi sebagai media pembelajaran yang valid dan praktis.

\section{Validitas modul pembelajaran biologi berbasis android}

Analisis lembar validasi modul pembelajaran biologi berbasis android oleh dosen dan guru didasarkan pada empat komponen evaluasi yaitu syarat didaktik, syarat konstruksi, syarat teknis dan kebahasaan. Hasil analisis data menunjukkan rata-rata nilai modul pembelajaran berbasis android $82,84 \%$ sehingga dikategorikan sangat valid. Modul pembelajaran biologi berbasis android memperoleh rata-rata nilai $84,02 \%$ dari validator sehingga dikategorikan sangat valid. Hal ini menunjukkan adanya kesesuaian modul pembelajaran biologi berbasis android dengan tuntutan Kompetensi Inti (KI), Kompetensi Dasar (KD), dan Indikator Pembelajaran.

Modul pembelajaran berbasis Android ditinjau dari syarat didaktik memperoleh ratarata nilai $79,99 \%$ dari validator sehingga dikategorikan valid. Hal ini menunjukkan bahwa modul pembelajaran biologi berbasis android ditinjau dari kompetensi dasar. Modul pembelajaran berbasis Android ditinjau dari syarat konstruksi memperoleh rata- rata nilai $87,49 \%$ dari validator sehingga dikategorikan sangat valid. Hal ini menunjukkan bahwa modul pembelajaran biologi berbasis android ditinjau dari komponen penyajian telah dilengkapi dengan indikator dan tujuan pembelajaran yang jelas. Selain itu, materi disajikan secara runtut sesuai dengan urutan indikator sehingga dapat memudahkan siswa belajar secara terarah. Hal ini sesuai dengan pendapat (Nasution, 2008) yang menyatakan bahwa tujuan pembelajaran yang jelas merupakan hal terpenting dalam mendesain suatu media pembelajaran supaya siswa terarah dalam penguasaan materi.

Aspek teknis berkenaan dengan tampilan modul pembelajaran biologi baik dari segi tampilan, jenis huruf, ukuran huruf, gambar dan video pelengkap. Berdasarkan aspek ini, materi ajar berbasis Android memperoleh rata-rata sebesar 83,33\% sehingga dikategorikan sangat valid. Hal ini menunjukkan bahwa modul pembelajaran biologi berbasis android menarik dari segi tampilannya, sehingga dapat menimbulkan motivasi bagi siswa untuk menggunakannya.

Modul pembelajaran biologi berbasis Android memperoleh rata-rata nilai $80,55 \%$ dari validator jika ditinjau dari aspek kebahasaan sehingga dikategorikan sangat valid. Hal ini menunjukkan tulisan dan bahasa pada modul pembelajaran biologi berbasis Android telah sesuai dengan kaidah dan standar yang berlaku, sehingga guru dan siswa dapat memahami modul pembelajaran biologi 
berbasis Android ini dengan mudah. Berdasarkan analisis data, secara keseluruhan rata-rata nilai hasil validasi modul pembelajarn berbasis Android ini adalah $82,84 \%$. Persentase ini menyatakan modul pembelajaran biologi berbasis Android yang dikembangkan dikategorikan valid oleh validator karena telah memenuhi keempat komponen evaluasi media pembelajaran.

\section{Praktikalitas modul pembelajaran biologi berbasis android}

Uji praktikalitas dilakukan oleh guru dan siswa. Hasil analisis angket uji praktikalitas modul pembelajaran biologi berbasis android oleh guru dan siswa menunjukkan bahwa modul pembelajaran biologi berbasis android yang dikembangkan memperoleh rata-rata nilai $87,92 \%$ dari guru sehingga dikategorikan sangat praktis dan $86,6 \%$ dari siswa sehingga dikategorikan sangat praktis. Aspek praktikalitas merupakan salah satu indikator produk yang dikembangkan menurut (Haviz, 2013) bahwa produk yang dirancang konsisten dan logis antara harapan dan aktual, harapan diartikan dengan produk akan bisa digunakan sedangkan aktual diartikan dengan produk bisa digunakan.

Berdasarkan analisis angket uji praktikalitas pada aspek kemudahan dalam penggunaan, modul pembelajaran biologi berbasis android memperoleh rata-rata nilai 95,00\% dari guru sehingga dikategorikan sangat praktis serta memperoleh rata-rata nilai $88,1 \%$ dari siswa sehingga dikategorikan sangat praktis. Hal ini menunjukkan bahwa modul pembelajaran biologi berbasis android yang dikembangkan telah memiliki petunjuk penggunaan yang jelas, mudah dipahami dan dioperasikan sehingga guru dan siswa cepat mempelajarinya.

Berdasarkan hasil analisis angket uji praktikalitas pada aspek manfaat, modul pembelajaran biologi berbasis android memperoleh rata-rata nilai $93,75 \%$ dari guru sehingga dikategorikan sangat praktis dan $87,1 \%$ dari siswa sehingga dikategorikan sangat praktis. Hal ini menunjukkan bahwa modul pembelajaran biologi berbasis android bermanfaat bagi guru yaitu mendukung peran guru sebagai fasilitator sedangkan manfaat bagi siswa yaitu dapat membantu siswa dalam memahami materi, membantu siswa belajar mandiri dan meningkatkan minat belajar siswa. hal yang sama juga ditemukan pada sebuah penelitian tentang pengembangan $\mathrm{CD}$ interaktif pada spermatogenesis (Haviz, 2018). Studi lain juga ditemukan mengenai hal yang sama dengan judul pembelajaran biologi menggunakan metode e-learning berbasis multiple intelligences pada materi sistem gerak manusia (Murdiyani, 2012) bahwa perangkat elearning berbasis Multiple Intelligences menggunakan MOODLE dapat meningkatkan efektivitas hasil belajar siswa. Model ini membuat pembelajaran Biologi menjadi lebih menyenangkan dan variasi.

Berdasarkan hasil analisis angket uji praktikalitas pada aspek efisiensi waktu pembelajaran, modul pembelajaran biologi berbasis android memperoleh rata-rata nilai $77,55 \%$ dari guru dan dikategorikan praktis dan $85,5 \%$ dari siswa sehingga dikategorikan sangat praktis. Hal ini menunjukkan bahwa modul pembelajaran biologi berbasis android yang dikembangkan dapat membantu siswa dalam pembelajaran mandiri serta dapat menjadikan waktu pembelajaran lebih efisien.

Secara keseluruhan, modul pembelajaran biologi berbasis android ini memperoleh rata-rata nilai $87,92 \%$ dari guru sehingga dikategorikan sangat praktis dan 86,6\% dari siswa sehingga dikategorikan sangat praktis. Hal ini menunjukkan bahwa modul pembelajaran biologi berbasis android mudah dipahami, mudah digunakan, dapat mengefisienkan waktu pembelajaran serta bermanfaat bagi guru maupun siswa. Selain itu, modul pembelajaran biologi ini memberikan suasana menyenangkan untuk digunakan karena berada dalam perangkat android yang sering digunakan siswa sehingga siswa tidak susah membawanya.

Keseluruhan hasil validasi dan uji praktikalitas menunjukkan modul pembelajaran biologi berbasis android yang dihasilkan sangat valid dan sangat praktis. Modul pembelajaran biologi berbasis android yang dikembangkan 
peneliti telah menyelesaikan permasa-lahan dalam pembelajaran biologi yang valid dan praktis khususnya pada materi sistem regulasi untuk siswa SMA/MA. Modul pembelajaran ini diharapkan dapat digunakan oleh siswa dan guru dalam pembelajaran di sekolah maupun di rumah.

\section{Analisis Pemograman}

Adapun analisis dalam pemograman pembuatan modul pembelajaran biologi berbasis android ini diantaranya yaitu:

a. Penggunaan modul pembelajaran biologi berbasis android ini minimal kapasitas memori handphone besar dari $45 \mathrm{MB}$.

b. Pembuatan modul pembelajaran bilogi berbasis android ini menggunakan aplikasi Android Studio dan Java Development Kit (JDK).

c. Penggunaan modul pembelajaran biologi berbasis android ini minimal android versi Jelly Bean sampai versi android terbaru sekarang ini.

d. Pembuatan modul pembelajaran biologi berbasis android ini harus terkoneksi ke jaringan internet, tetapi dalam pengguaan modul pembelajaran biologi berbasis android ini tidak terkoneksi ke dalam jaringan internet atau bersifat offline.

\section{KESIMPULAN}

Berdasarkan hasil penelitian yang telah dilakukan, mengenai modul pembelajaran biologi berbasis android disimpulkan bahwa telah dihasilkan modul pembelajaran biologi berbasis android tentang materi sistem regulasi untuk siswa SMA/MA yang valid dan praktis. Berdasarkan penilaian validator, modul pembelajaran biologi berbasis android di kategorikan sangat valid. Karna nilai rata-rata kevalidannya 82,84. Berdasarkan penilaian guru mata pelajaran biologi berbasis android di kategorikan sangat praktis didapat hasil ratarata 87,92 dan berdasarkan penilaian siswa modul pembelajaran biologi di kategorikan sangat praktis dan memperoleh rata-rata nilai 86,6 . Modul pembelajaran biologi berbasis android yang peneliti kembangkan layak untuk digunakan dalam proses pembelajaran.

\section{DAFTAR KEPUSTAKAAN}

Adelheid, A., \& Aqilha, P. (2013). Tip Trik Android dan Blackberry. Yogyakarta: C.V Andi Offset.

Arsyad, A. (2010). Media Pembelajaran. Jakarta: Rajawali Pers.

Haviz, M. (2013). Research and Development; Penelitian di Bidang Kependidikan yang Inovatif, Produktif dan Bermakna. Ta'dib, 16(1), 28-43.

Haviz, M. (2018). Computer-assisted Biology Learning Materials: Designing and Developing an Interactive $\mathrm{CD}$ on Spermatogenesis. IOP Conference Series: Materials Science and Engineering, 335(1). $\quad$ https://doi.org/10.1088/1757899X/335/1/012081

Istiyanto, J. E. (2013). Pemograman Smartphone Menggunakan SDK Android dan Hacking Android. Yogyakarta: Graha Ilmu.

Kustandi, C., \& Sutjipto, B. (2013). Media Pembelajaran Manual dan Digital. Bogor: Ghalia Indonesia.

Mulyasa, E. (2009). Pengembangan Standar Kompetensi dan Kompetensi Dasar. Bandung: PT Remaja Rosdakarya.

Murdiyani, I. (2012). Innovative Journal of Curriculum and Educational Technology PEMBELAJARAN BIOLOGI MENGGUNAKAN METODE ELEARNING BERBASIS MULTIPLE INTELLIGENCES PADA MATERI SISTEM GERAK MANUSIA. Innovative Journal of Curriculum and Educational Technology, 1(1). Retrieved from http://journal.unnes.ac.id/sju/index.php/uj et

Nasution, S. (2008). Berbagai Pendekatan Dalam Prose Belajar Mengajar. Jakarta: Bumi Aksara.

Sugiyono. (2007). Metode Penelitian Pendidikan. Bandung: Alfabeta.

Suprihatiningrum, J. (2014). Pedoman Kinerja, 
Pratama, H., Eliwatis., Fajar, N. 2018. Pengembangan Modul Pembelajaran Biologi Berbasis Android pada Materi Sistem Regulasi untuk Siswa SMA/MA. Sainstek : Jurnal Sains dan Teknologi. 10 (2) : 43-55

Kualifikasi, \& Kompetensi Guru. Yogjakarta: Ar-Ruzz Media.

Yogyakarta: Graha Ilmu. ryadi, M. T. (2014). Berdagang yang Cetar di Android. Yogyakarta: CV. Andi Offset.

Trianto. (2012). Mendesain Model Pembelajaran Inovatif-Progresif. Jakarta: Bumi Aksara. Sutopo, A. H. (2012). Tegnologi Informasi Dan Komunikasi Dalam Pendidikan. 